\title{
BMJ Open Status and contents of physical activity recommendations in European Union countries: a systematic comparative analysis
}

\author{
Peter Gelius (D) , ${ }^{1}$ Antonina Tcymbal, ${ }^{1}$ Karim Abu-Omar, ${ }^{1}$ Romeu Mendes (D) ,2 \\ Sara Tribuzi Morais (D) , ${ }^{3}$ Stephen Whiting, ${ }^{2,4}$ Joao Breda ${ }^{4}$
}

To cite: Gelius $P$, Tcymbal A, Abu-Omar K, et al. Status and contents of physical activity recommendations in European Union countries: a systematic comparative analysis. BMJ Open 2020;10:e034045. doi:10.1136/ bmjopen-2019-034045

- Prepublication history for this paper is available online. To view these files, please visit the journal online (http://dx.doi. org/10.1136/bmjopen-2019034045).

Received 03 September 2019 Revised 02 December 2019 Accepted 30 December 2019

Check for updates

(C) Author(s) (or their employer(s)) 2020. Re-use permitted under CC BY-NC. No commercial re-use. See rights and permissions. Published by BMJ.

${ }^{1}$ Department of Sport Science and Sport, FAU, Erlangen,

Germany

${ }^{2}$ EPIUnit - Instituto de Saúde

Pública, Universidade do Porto, Porto, Portugal

${ }^{3}$ Faculdade de Desporto, Universidade do Porto, Porto, Portugal

${ }^{4}$ Division of Noncommunicable Diseases and Promoting Health through the Life-course, World Health Organization Regional Office for Europe, Copenhagen, Denmark

Correspondence to

Dr Peter Gelius;

peter.gelius@fau.de

\section{ABSTRACT}

Objectives We analysed the information on current national physical activity recommendations in all EU Member States provided by governments in a joint EU/ WHO survey on the implementation status of the EU Council Recommendation on Health-Enhancing Physical Activity across Sectors.

Design Cross-sectional survey.

Participants The representatives of the 28 EU Member State governments to the EU Physical Activity Focal Point Network.

Outcome measures National recommendations on: (A) minimum frequency, duration, intensity and lengths of bouts of physical activity, (B) preventing inactivity or sedentary behaviour and (C) further recommendations for additional health benefits, obesity prevention and specific types of activity.

Results An official document could be located for 23 of the $28 \mathrm{EU}$ Member States, while four are currently developing recommendations. For children and adolescents, most countries follow the 2010 WHO Global Recommendations for Physical Activity, but there are notable differences in the delimitation of age groups. 14 countries also followed WHO in their recommendations for adults, and 11 countries have additional advice on avoiding inactivity and sitting among adults. 18 Member States have recommendations for older adults, 12 of which follow WHO. Thirteen countries also address at least one special population (eg, pregnant women, people with disabilities and people with chronic diseases), but the level of detail varies substantially between countries.

Conclusions The large majority of EU Member States either has physical activity recommendations in place or is in the process of developing them. There is a general tendency to use the WHO Global Recommendations as a basis, with the greatest variation observable for children and adolescents. Comparing results with a previous round of data collection shows that the number of EU countries with physical activity recommendations is increasing and that both special groups and sedentary behaviour have become more important in recent years.

\section{INTRODUCTION}

Global efforts to promote physical activity (PA) have intensified in recent years,
Strengths and limitations of this study

- This is the first scientific analysis emanating from the 2018 round of data collection to monitor the implementation of the EU Council Recommendation on Promoting Health-Enhancing Physical Activity (HEPA) across Sectors.

- It builds on information obtained directly from national governments and gathered jointly by the European Commission and the WHO Regional Office for Europe.

- The instrument used for data collection is based on the WHO HEPA Policy Audit Tool an is unique in providing comparable data for all 28 EU countries.

- By comparing the data with an earlier survey using the same instrument, this study also allows for monitoring the progress made in this area of health promotion policy in recent years.

- Limitations include a restriction to documents published before April 2018, difficulties in identifying and obtaining all relevant documents and the language barrier involved in analysing data in 21 different languages.

culminating in key WHO publications such as the 2004 WHO Global Strategy on Diet, PA and Health, ${ }^{1}$ the PA Strategy for the WHO European Region 2016-2025 ${ }^{2}$ and the 2018 Global Action Plan on PA. ${ }^{3}$ Common advice found in all these documents is for Member States to develop national recommendations on how active their population should be in order to promote health and prevent disease. WHO's 2010 Global Recommendations on PA for Health, ${ }^{4}$ which in turn draw extensively on the 2008 PA Guidelines for Americans $^{5}$ and earlier work by organisations in the USA, such as the Centers for Disease Control and Prevention (CDC) and American College of Sports Medicine (ACSM), ${ }^{6}$ are often cited as a reference document for such recommendations. The European Union (EU) has also been increasingly active in the field, with 
efforts building on the $2008 \mathrm{EU}$ PA Guidelines ${ }^{7}$ and the 2013 EU Council Recommendation on Health-Enhancing Physical Activity (HEPA) across Sectors. ${ }^{8}$ Like WHO, the EU encourages Member States to publish national PA recommendations for health.

While there is only limited evidence that such national recommendations can, by themselves, increase the share of individuals who reach sufficient levels of $\mathrm{PA},{ }^{9}$ the process of developing them may serve as a starting point for putting the topic of PA promotion on the national agenda. ${ }^{10}$ Both academic publications on the subject ${ }^{1011}$ and actual guideline documents (including by $\mathrm{WHO},{ }^{4}$ the $\mathrm{EU}^{12}$ and the USA) ${ }^{5}{ }^{13}$ identify policymakers and health promotion professionals as the main target audiences for national PA recommendations and emphasise that such guidelines may constitute a key information resource, guide national goal-setting and policy development, and serve as primary benchmarks for PA monitoring and surveillance initiatives.

Given both their political relevance and their potential to spark new policy, it is important to monitor whether national governments are making progress in developing national PA recommendations. Guideline publications and updates by countries such as the USA, ${ }^{513}$ Canada $^{1415}$ and Australia ${ }^{16}{ }^{17}$ have received widespread attention. For the WHO European Region, Kahlmeier $e t \mathrm{al}^{11}$ provided an overview of existing national PA recommendations based on data collected in 2011. They found that 21 out of the 53 nations in the entire region and 16 out of the $28 \mathrm{EU}$ Member States had such recommendations in place. Some years later, Breda et $a l^{18}$ analysed data collected in 2015 by the European Commission (EC) and the WHO Regional Office for Europe to monitor the progress of implementation of the Council Recommendation on HEPA across Sectors $^{8}$ and to produce the EU/WHO PA Country Factsheets for the EU Member States of the WHO European Region. ${ }^{19}$ They noted that 19 of the 27 participating EU countries had reported national PA recommendations. However, a more detailed analysis of these recommendations was beyond the scope of this overview article.

As part of a regular update of this information, ${ }^{19} \mathrm{WHO}$ and the EC collected new information on national PA recommendations in 2018. These data provide a unique opportunity to revise the overview of existing recommendations in the EU and for a detailed comparison of target groups, age bracket definitions and recommended amounts and types of PA across nations. This information may be useful both to further monitor the progress of recommendation development in the EU and as a potential source of inspiration for other countries in the WHO European Region.

\section{METHODS}

\section{Data collection}

Information about national PA recommendations was obtained from the 2018 joint survey by the EC and WHO Europe, which employed a questionnaire covering all 23 indicators of the Council Recommendation on
HEPA across Sectors. Indicator 1 is dedicated exclusively to national PA recommendations. Specific items included the development status of national PA recommendations (eg, not planned, under development and formally adopted), the age groups covered (children and adolescents, adults or older adults), special populations addressed (eg, children $<5$ years, frail people or those aged $\geq 85$ years, pregnant or breastfeeding women, people with disabilities or people with chronic diseases) and links to relevant documents. ${ }^{19}$

The questionnaire was sent to the EU Physical Activity Focal Points in all 28 EU Member States in January 2018. Focal Points are PA experts officially nominated by their governments to support data collection. They usually work in national ministries of health, ministries of sport or related national agencies. They were asked to liaise with relevant national institutions and stakeholders to fill out the questionnaire within 3 months. All 28 Focal Points completed the questionnaire. WHO reviewed the responses to ensure data quality, obtained additional information and clarification where necessary and prepared draft summaries. After a final review by the Member States, the collated information was published in the form of updated PA Country Factsheets. ${ }^{19}$

\section{Verification of information on national PA recommendations}

For this article, we retrieved and reviewed the answers for indicator 1 of the survey from the original dataset. We followed the links to national PA recommendations provided by countries and downloaded the official documents. In cases where the link was missing or broken, an additional search was conducted on the internet. Where this still yielded no results, fellow academics from the field of PA in the respective nations were contacted to in order to obtain the document. The contents of recommendations in languages other than English or German were translated online via Google Translate. Translations were verified against the original versions by expert native speakers to confirm their factual correctness.

\section{Data analysis}

The following information was extracted from national PA recommendation documents: (1) minimum recommendations on frequency, duration, intensity and lengths of bouts of PA, (2) recommendations on preventing inactivity or sedentary behaviour (eg, prolonged sitting) and (3) any further PA recommendations for additional health benefits, obesity prevention or specific types of PA. We extracted these data for all age brackets (children, adults and older adults) and special population groups (eg, people with health-related conditions) listed in the respective document. Individual country results were then compared with the WHO Global Recommendations on PA for Health ${ }^{4}$ and recommendations from the other EU Member States.

Patient and public involvement

No patient involved. 
Table 1 National physical activity recommendations in EU Member States by year and population group(s) covered

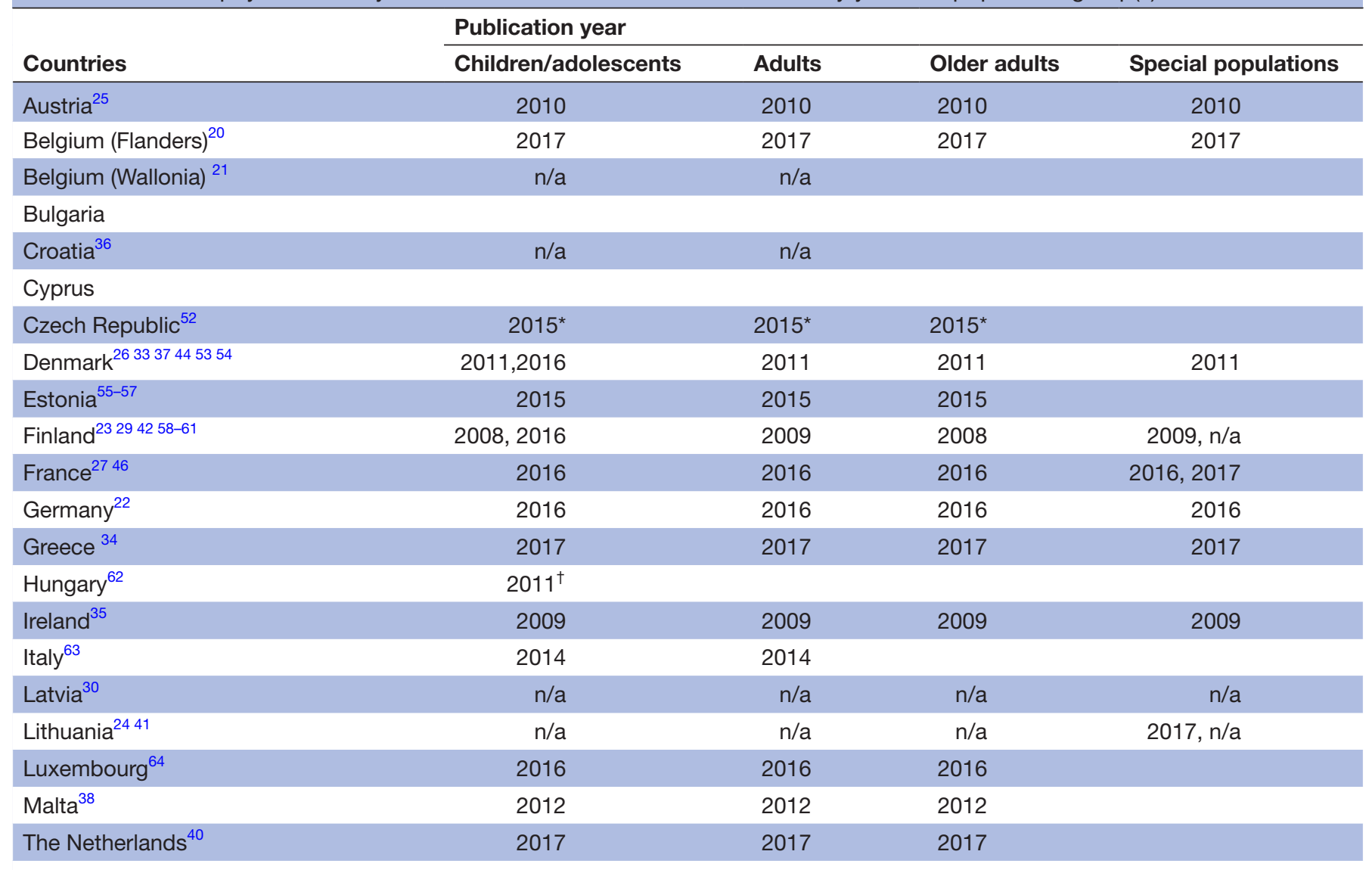

Poland

Portugal

Romania

\begin{tabular}{lrrrr} 
Slovakia $^{65}$ & 2017 & 2017 & & \\
Slovenia $^{66}$ & 2015 & 2015 & 2015 & 2015 \\
Spain $^{31}$ & 2015 & 2015 & 2015 & 2011 \\
Sweden $^{4345}$ & n/a & 2011 & 2011 & 2011,2017 \\
\hline UK $^{3267}$ & 2011 & 2011 & 2011 & 2 \\
\hline
\end{tabular}

${ }^{*}$ Document does not include information about the duration, intensity and frequency of PA.

†Document does not include information about the duration, intensity and frequency of PA but about daily mandatory PE in elementary and secondary schools.

$\mathrm{n} / \mathrm{a}$, year of publication is not available; PA, physical activity; PE, physical education.

\section{RESULTS}

An official document outlining national PA recommendations could be located for $23(82.1 \%)$ of the $28 \mathrm{EU}$ Member States. For two countries, the official PA recommendations did not contain any specific information about minimum recommended PA levels. Four countries reported that they are in process of developing PA recommendations, and one country reported there are currently no plans to develop dedicated PA recommendations. Belgium has separate documents for the Flemish ${ }^{20}$ and Walloon ${ }^{21}$ regions, both of which were included in the analysis. In total, 22 documents (21 national documents plus an additional one for Belgium), published between 2008 and 2018, were analysed in greater detail (table 1).

\section{Children and adolescents}

Table 2 presents a detailed overview of existing PA recommendations for children and adolescents in EU Member States. For this target group, WHO recommends at least $60 \mathrm{~min}$ of moderate-intensity to vigorous-intensity PA every day, adding that greater amounts will provide further health benefits. ${ }^{4}$

Regarding duration and frequency of PA, all recommendations suggest the same minimum as WHO, that is, 60 min per day. The two exceptions are Germany, ${ }^{22}$ which calls for at least $90 \mathrm{~min}$, and Finland, ${ }^{23}$ which 


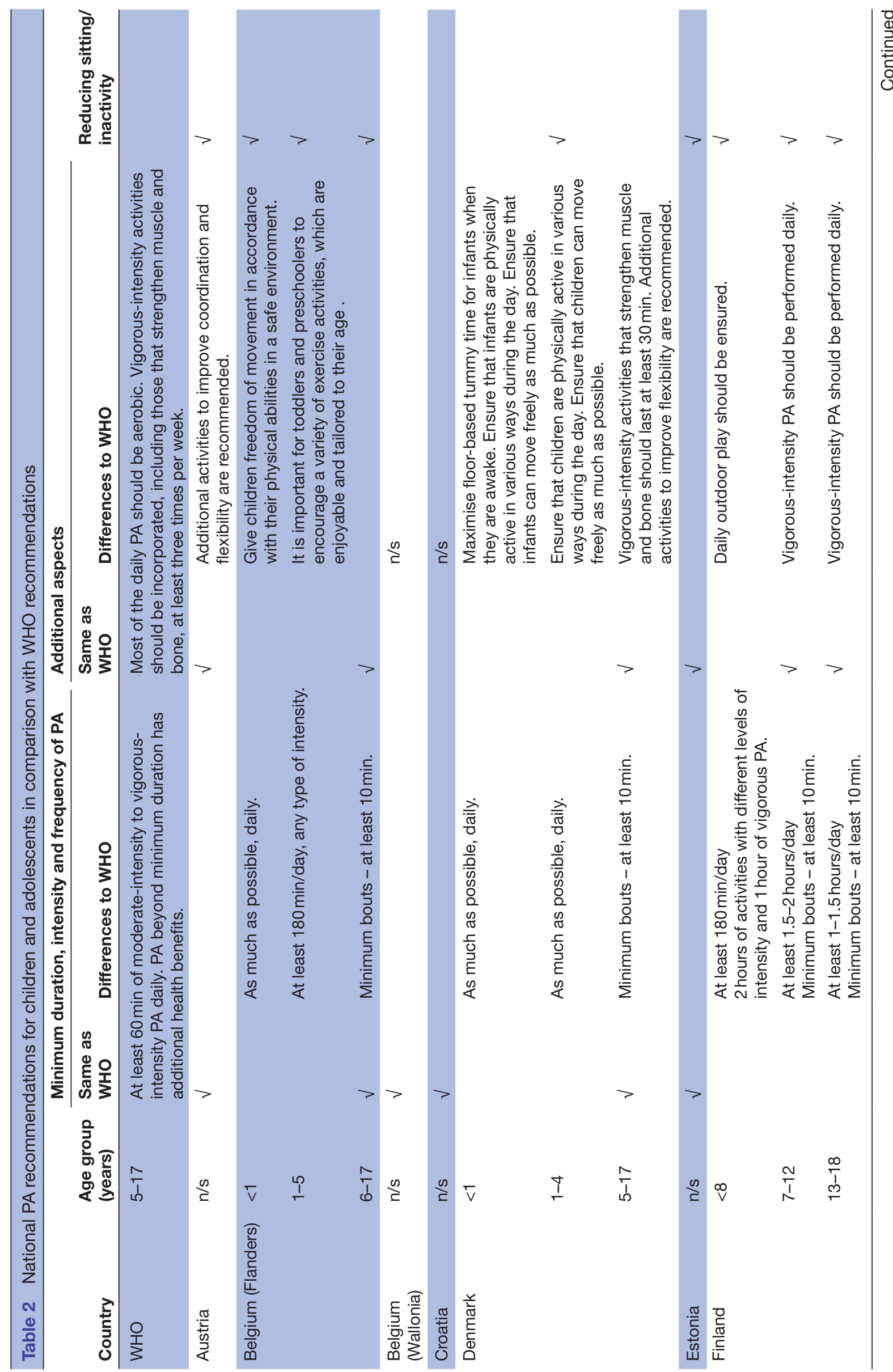




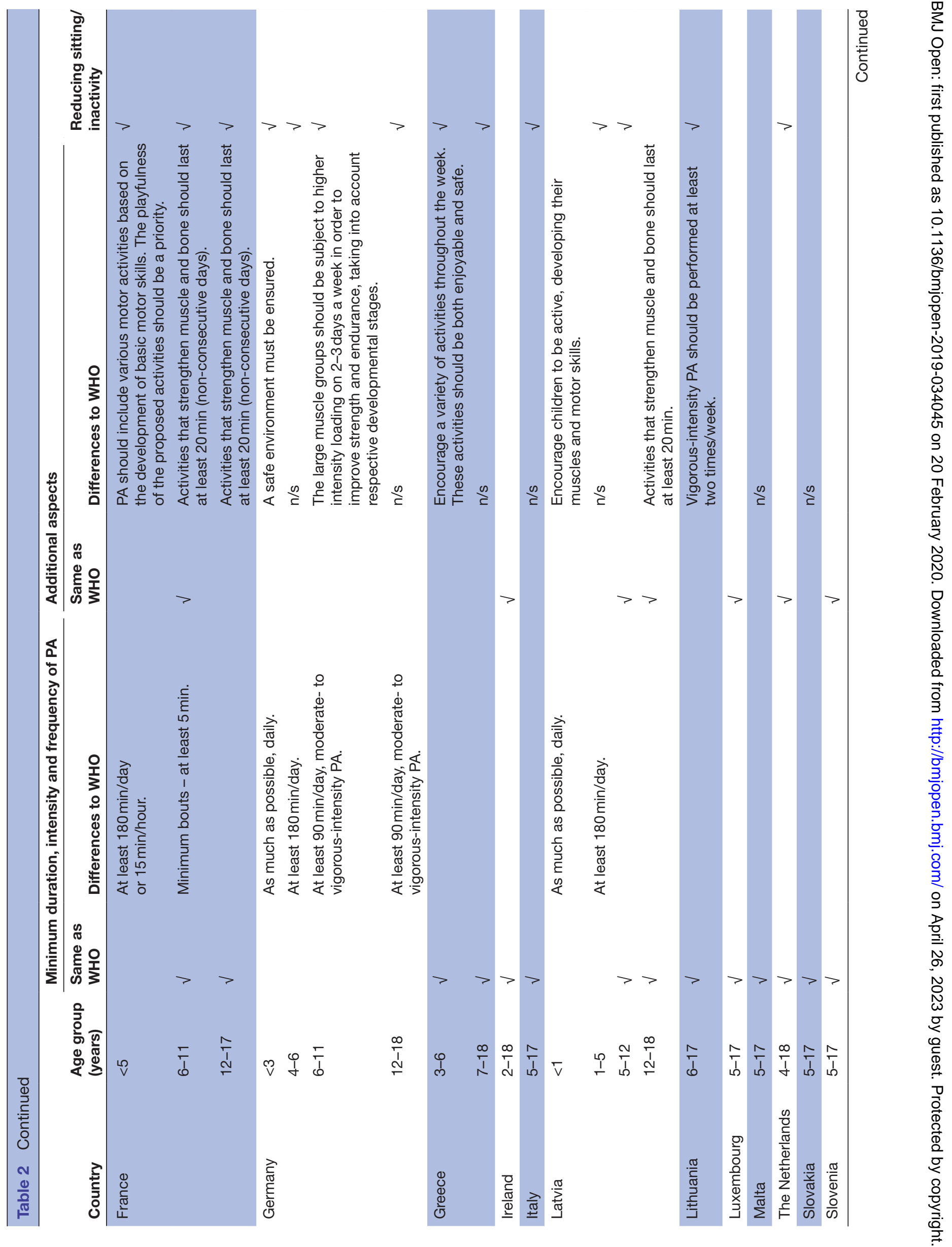




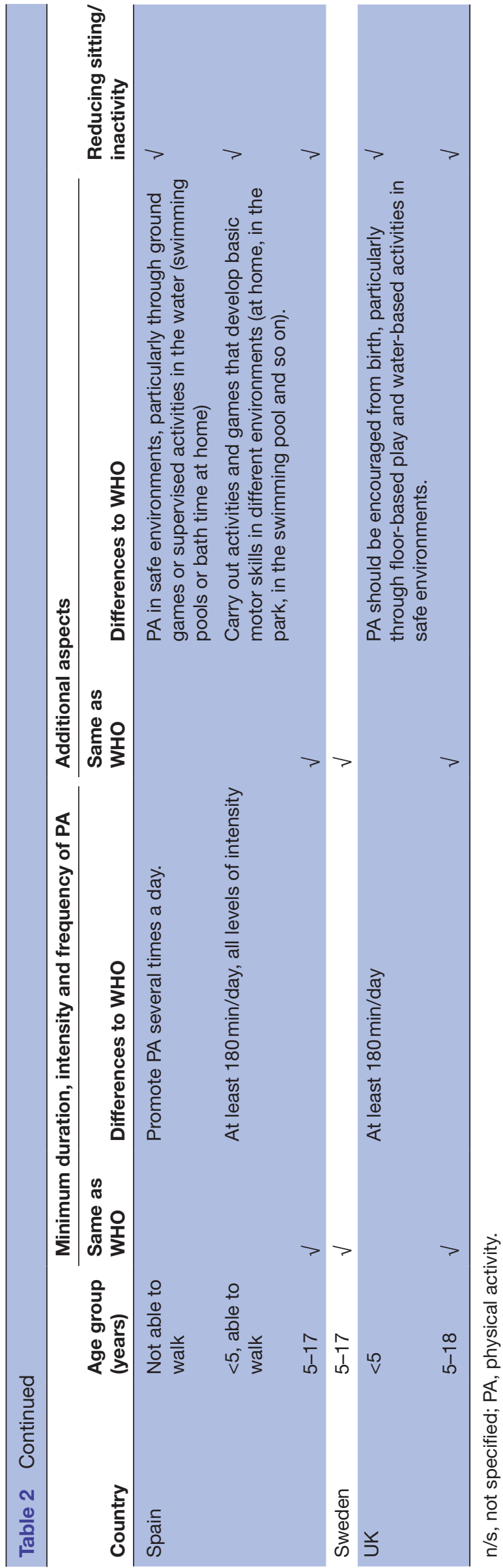

stipulates $90-120$ min per day for children (7-12 years) and 60-90 min per day for adolescents (13-18 years). Eleven countries mention that any amount exceeding minimum recommendations will provide additional health benefits. Lithuania suggests that, to achieve additional health benefits, 'PA time must be longer than the minimum $(60 \mathrm{~min})$ and last for at least 1.5-2 hours (120 min) daily'. ${ }^{24}$ Like WHO, 16 countries specify the intensity of recommended PA as moderate to vigorous.

As additional aspects, WHO emphasises that most of the daily PA should be aerobic and that vigorous-intensity activities should be incorporated at least three times per week to strengthen muscle and bone. ${ }^{4}$ Recommendations in $14 \mathrm{EU}$ Member States mirror this, while Lithuania $^{24}$ advocates at least two times per week and Finland ${ }^{23}$ proposes to do it every day. Germany mentions that, for children aged 6-11 years, 'the large muscle groups should be subject to higher-intensity loading on two to three days a week in order to improve strength and endurance, taking into account respective developmental stages'. ${ }^{22}$ Austria $^{25}$ and Denmark ${ }^{26}$ additionally recommend to include activities to improve flexibility.

Belgium (Flanders),${ }^{20}$ Denmark, ${ }^{26}$ Finland ${ }^{23}$ and Lithuania $^{24}$ specify that minimum bouts of PA should be at least 10 min, while France ${ }^{27}$ suggests at least 5 min for children from 6 years to 11 years. Minimum duration is part of WHO's recommendations for adults (see below) but not for children. Also transcending WHO recommendations, 15 national documents include sections on avoiding extended periods of inactivity and sitting among children and adolescents.

The results indicate notable differences in the handling of age subgroups among children and adolescents (see figure 1): in 2019, WHO published dedicated PA recommendations for children under the age of 5 years, ${ }^{28}$ but at the time of data collection, WHO recommendations only addressed children aged 5-17 years. Six countries used exactly the same age range. Others had already developed additional recommendations for children younger than 5 years (nine countries), or they had extended the age range of their recommendations to this group (two countries). Seven countries (Belgium (Flanders), ${ }^{20}$ Finland, ${ }^{29}$ France, ${ }^{27}$ Germany, ${ }^{22}$ Latvia, ${ }^{30}$ Spain $^{31}$ and the UK) ${ }^{32}$ recommend for children under 5 years to be active for at least 180 min per day. Denmark ${ }^{33}$ calls for as much PA 'as possible', while Greece ${ }^{34}$ and Ireland ${ }^{35}$ recommend the same amount as for older children, that is, at least $60 \mathrm{~min}$ per day. In addition, seven countries included individuals aged 18 years in their recommendations for adolescents, and six countries introduced multiple age brackets with specific recommendations.

\section{Adults}

A comparison of the 21 national PA recommendations for adults (18-64 years) with the respective WHO recommendation is presented in table 3 . In general, WHO advises adults to engage in at least $150 \mathrm{~min}$ of moderate-intensity aerobic PA throughout the week, or at least $75 \mathrm{~min}$ of 


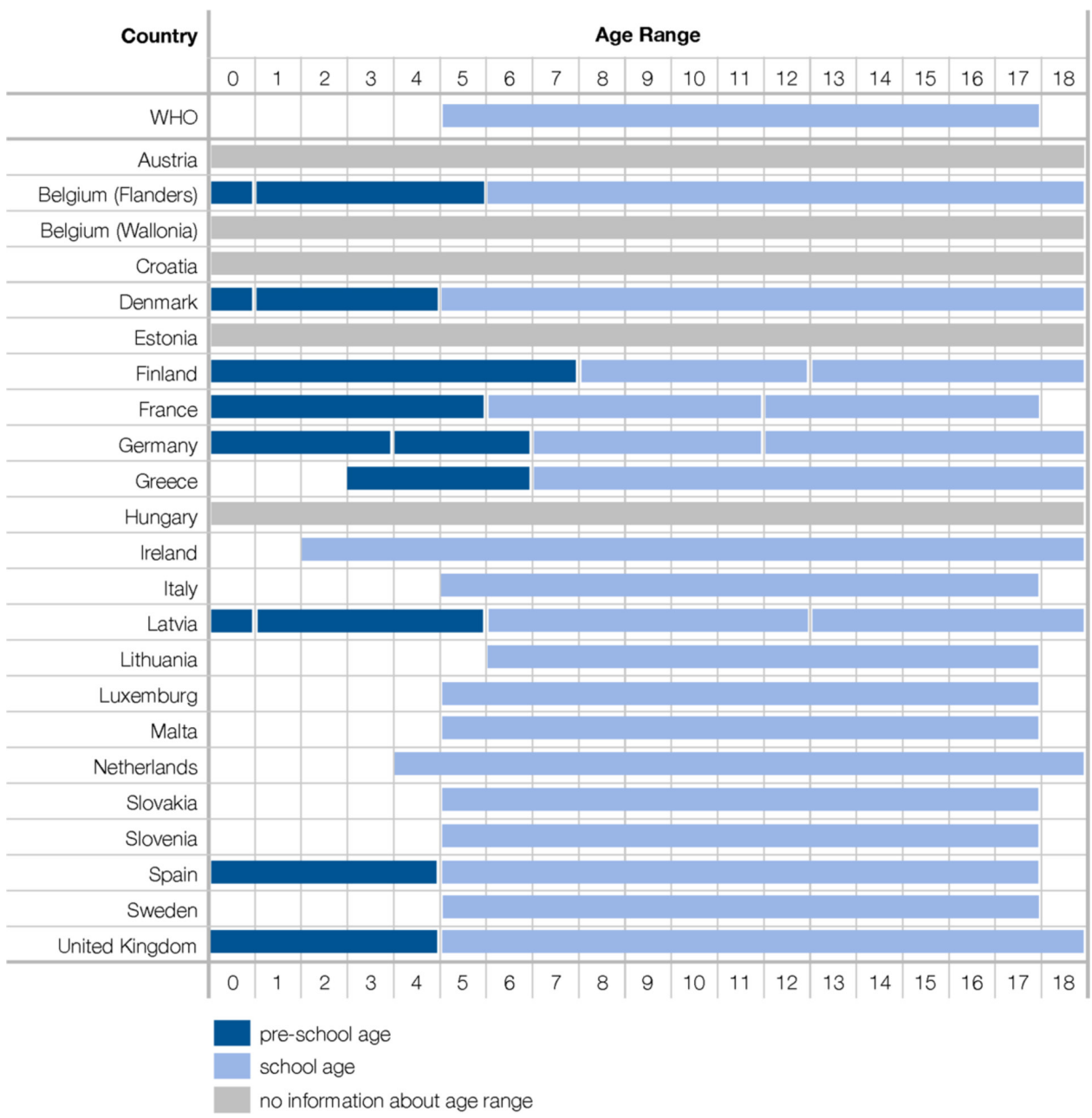

Figure 1 Comparison of age ranges in national PA recommendations for children and adolescents. PA, physical activity.

vigorous-intensity aerobic PA, or an equivalent combination of moderate-intensity and vigorous-intensity PA. PA should be performed in bouts of at least $10 \mathrm{~min}$. Additional benefits can be gained from increasing moderate PA to $300 \mathrm{~min}$ per week, by engaging in $150 \mathrm{~min}$ of vigorous $\mathrm{PA}$, or through an equivalent combination of both.

For 14 nations, recommendations on minimum duration, intensity and frequency of PA are fully in line with WHO. Croatia, ${ }^{36}$ Denmark, ${ }^{37}$ France, ${ }^{27}$ Greece, ${ }^{34}$ Lithuania, ${ }^{24}$ Malta $^{38}$ and Belgium (Wallonia) ${ }^{21}$ recommend 30 min of PA per day on 5 or more days per week, probably echoing older recommendations published jointly by the ACSM and the CDC in $1995^{6}$ and updated in $2007 .{ }^{39}$ Like WHO, 14 countries recommend to count only activities with a duration of at least 10 min, while France ${ }^{27}$ and the Netherlands ${ }^{40}$ suggest that bouts of less than $10 \mathrm{~min}$ may also be counted. Seven countries mirror WHO's recommendations regarding additional health benefits, while five countries merely mention that health can be further improved by performing PA above the recommended minimum.

France, ${ }^{27}$ Ireland $^{35}$ and Lithuania $^{24}$ recommend increasing levels to $60 \mathrm{~min}$ of moderate PA per day on at least 5 days per week, or to an equivalent amount of vigorous PA in order to achieve additional health benefits.

An additional aspect of the WHO recommendations are muscle-strengthening activities involving major muscle groups, which should be performed on 2 or more days of the week. ${ }^{4}$ Sixteen of the EU Member States also urge their citizens to do this. France diverges slightly by stipulating that strength training should be performed 1-2 times per week, with 1-2 days' recovery time in between, and stretching at least 2-3 times per week. ${ }^{27}$ Denmark $^{37}$ recommends to also add activities that increase flexibility. In addition, Ireland, ${ }^{35}$ Malta $^{38}$ and the $\mathrm{UK}^{32}$ have specific recommendations on reducing or maintaining body weight. Eleven countries also have additional recommendations on avoiding long periods of inactivity and sitting among adults.

\section{Older adults}

Eighteen EU Member States have national PA recommendations for older people that were available for analysis. The contents of these are shown in table 4. WHO's basic recommendations for older adults $(65+$ years $)$, which are identical to those for adults aged 18-64 years (see above), have been directly adopted by 12 countries. In the six 
Table 3 National PA recommendations for adults (18-64 years) in comparison with WHO recommendations

Minimum duration, intensity and frequency of PA

\begin{tabular}{|c|c|}
\hline Country & Differences to WHO \\
\hline WHO & $\begin{array}{l}\text { At least } 150 \text { min of moderate-intensity aerobic PA } \\
\text { throughout the week, or } 75 \text { min of vigorous-intensity } \\
\text { aerobic PA, or an equivalent combination of both. Bouts } \\
\text { should be at least } 10 \text { min each. For additional health } \\
\text { benefits, increase moderate PA to } 300 \text { min per week, } \\
\text { or engage in } 150 \text { min of vigorous PA/an equivalent } \\
\text { combination of both. }\end{array}$ \\
\hline
\end{tabular}

Austria $\quad V$

Belgium

(Flanders)

$\sqrt{ }$

At least 150 min of moderate-intensity

PA per week, spread over 5 days and preferably all days of the week, at least $30 \mathrm{~min}$ per day. Alternatively, $75 \mathrm{~min}$ of vigorous-intensity PA, best spread over, eg, 3 days in bouts of 25 min. Inactive adults over the age of 45 should consult a general practitioner before starting vigorous-intensity PA.

Belgium At least $30 \mathrm{~min} /$ day

(Wallonia)

Croatia

Denmark

\section{At least $30 \mathrm{~min} /$ day of moderate intensity} PA

PA for at least 30 min per day. The activity $\sqrt{ }$ should be of moderate to high intensity and extend beyond the usual short-term daily activities. If the $30 \mathrm{~min}$ are divided, each activity should last at least $10 \mathrm{~min}$.
Additional aspects

Same as Reducing sitting/

inactivity

Muscle-strengthening activities should be done involving major muscle groups on 2 or more days a week.

$\checkmark$

$\sqrt{ }$

\section{$\sqrt{ }$}

$n / s$

High-intensity training should last at least 20 min. Incorporate activities that increase bone strength and flexibility.

\begin{tabular}{|c|c|c|c|c|c|}
\hline Estonia & $\sqrt{ }$ & & $\sqrt{ }$ & & $\sqrt{ }$ \\
\hline Finland & $\sqrt{ }$ & & $\sqrt{ }$ & & $\sqrt{ }$ \\
\hline France & & $\begin{array}{l}\text { At least } 30 \mathrm{~min} / \text { day at least } 5 \text { days per } \\
\text { week, moderate to vigorous intensity. } \\
\text { Vigorous-intensity PA is recommended } \\
\text { in short bouts ( } 5-10 \mathrm{~min} \text { ) repeated } \\
\text { throughout the day ( } 3-4 \text { times). }\end{array}$ & & $\begin{array}{l}\text { Strength training is } \\
\text { recommended } 1-2 \\
\text { times a week, with } \\
1-2 \text { days to recover } \\
\text { between sessions. } \\
\text { Stretching at least } \\
2-3 \text { times a week. }\end{array}$ & $\sqrt{ }$ \\
\hline Germany & $\sqrt{ }$ & & $\sqrt{ }$ & & $\sqrt{ }$ \\
\hline Greece & & At least $30 \mathrm{~min} /$ day & & $\mathrm{n} / \mathrm{s}$ & $\sqrt{ }$ \\
\hline Ireland & $\sqrt{ }$ & & $\sqrt{ }$ & & \\
\hline Italy & $\sqrt{ }$ & & & $\mathrm{n} / \mathrm{s}$ & \\
\hline Latvia & $\sqrt{ }$ & & $\sqrt{ }$ & & \\
\hline Luxembourg & $\sqrt{ }$ & & $\sqrt{ }$ & & \\
\hline Malta & & $\begin{array}{l}\text { At least } 30 \text { min of moderate-intensity PA } \\
5 \text { days per week; or } 20 \text { min of vigorous- } \\
\text { intensity PA } 3 \text { days per week; or an } \\
\text { equivalent combination of moderate and } \\
\text { vigorous-intensity PA. }\end{array}$ & $\sqrt{ }$ & & \\
\hline
\end{tabular}

Continued 
Table 3 Continued

\begin{tabular}{lllll}
\hline & \multicolumn{2}{l}{ Minimum duration, intensity and frequency of PA } & & \multicolumn{2}{l}{ Additional aspects } \\
\cline { 2 - 3 } Country & $\begin{array}{l}\text { Same as } \\
\text { WHO }\end{array}$ & Differences to WHO & $\begin{array}{l}\text { Same as } \\
\text { WHO }\end{array}$ & Differences to WHO \\
inactivity
\end{tabular}

n/s, not specified; PA, physical activity.

other cases, the original national recommendation for adults differs from that by WHO, but they also follow the practice of carrying over these recommendations to older people. All identified documents add that persons who cannot achieve minimum PA levels should be as physically active as their abilities and conditions allow.

WHO adds that older people should engage in musclestrengthening involving major muscle groups on 2 or more days a week, and that those with poor mobility should perform PA to enhance balance and prevent falls on 3 or more days per week. In general, all national documents also include these additional aspects. No country has specific recommendations for older adults on reducing or maintaining weight, but 11 add recommendations on avoiding long periods of inactivity and sitting.

\section{Special groups}

As illustrated in table 5, 13 countries also have national PA recommendations for at least one special population (eg, frail people or those aged $\geq 85$ years, pregnant or breastfeeding women, people with disabilities or people with chronic diseases). However, the level of detail of these recommendations varies significantly, as well as the publication format: Finland published recommendations for all special groups as separate documents, and Lithuania has a separate document for parents with small children. All other countries mentioned special groups in their general document with recommendations on PA. Twelve countries have recommendations for women during pregnancy and breastfeeding. Most of these suggest that healthy women during pregnancy and breastfeeding follow the same recommendations for adults. Two countries (France ${ }^{27}$ and Lithuania ${ }^{41}$ ) have specific recommendations on the duration, frequency or intensity of PA during pregnancy. In addition, Lithuania ${ }^{41}$ also addresses parents with small children.

Special recommendations for disabled people are provided by nine countries. These are mostly identical to the general recommendations but also include the reservation that they should be adapted to the level and structure of the disability and to physical conditions. Finland ${ }^{42}$ has specific recommendations for three types of disability: adults with a disease or disability that causes some difficulty in movement; adults who use an assistive device for walking; and adults who use wheelchairs. Sweden ${ }^{43}$ also specifically mentions that children and adolescences with disabilities should try to reach PA levels recommended for their age under the supervision of a health professional.

Nine countries (Austria, ${ }^{25}$ Denmark, ${ }^{44}$ Finland, ${ }^{42}$ France, ${ }^{27}$ Germany, ${ }^{22}$ Ireland, ${ }^{35}$ Latvia,${ }^{30}$ Lithuania ${ }^{24}$ and Sweden ${ }^{45}$ ) have separate recommendations for people with chronic diseases, generally encouraging them to be as active as is recommended for the general population of their age. Latvia ${ }^{30}$ and Lithuania ${ }^{24}$ additionally recommend to seek medical advice before starting to exercise. France $^{27}$ developed a special recommendation on PA for people with cancer. ${ }^{46}$

Two countries (France ${ }^{27}$ and Greece) ${ }^{34}$ have recommendations for postmenopausal women, and six countries reported that they have special recommendations for very elderly adults (85+ years). However, no specific documents for this adult group could be identified in the context of this study.

\section{DISCUSSION}

This article has collected and analysed data on national PA recommendations for EU Member States. Such an endeavour naturally comes with a number of limitations and potential caveats. First, the analysis is limited to documents published before April 2018 and does not cover recommendations developed in several Member States since then. Examples include Hungary, ${ }^{47}$ Italy, ${ }^{48}$ Malta $^{49}$ and the UK. ${ }^{50}$ Likewise, important reference documents have received updates in the meantime or are about to do so, including the US Guidelines for Americans (second edition published in 2018), ${ }^{13}$ the WHO recommendations for children under the age of 5 (published in 2019) ${ }^{28}$ and the WHO Global Recommendations on Physical Activity in Youth, Adults and Older Adults (update to be published in 2020).$^{51}$ Moreover, the visibility of national PA recommendations varies significantly, making some documents more difficult to identify 


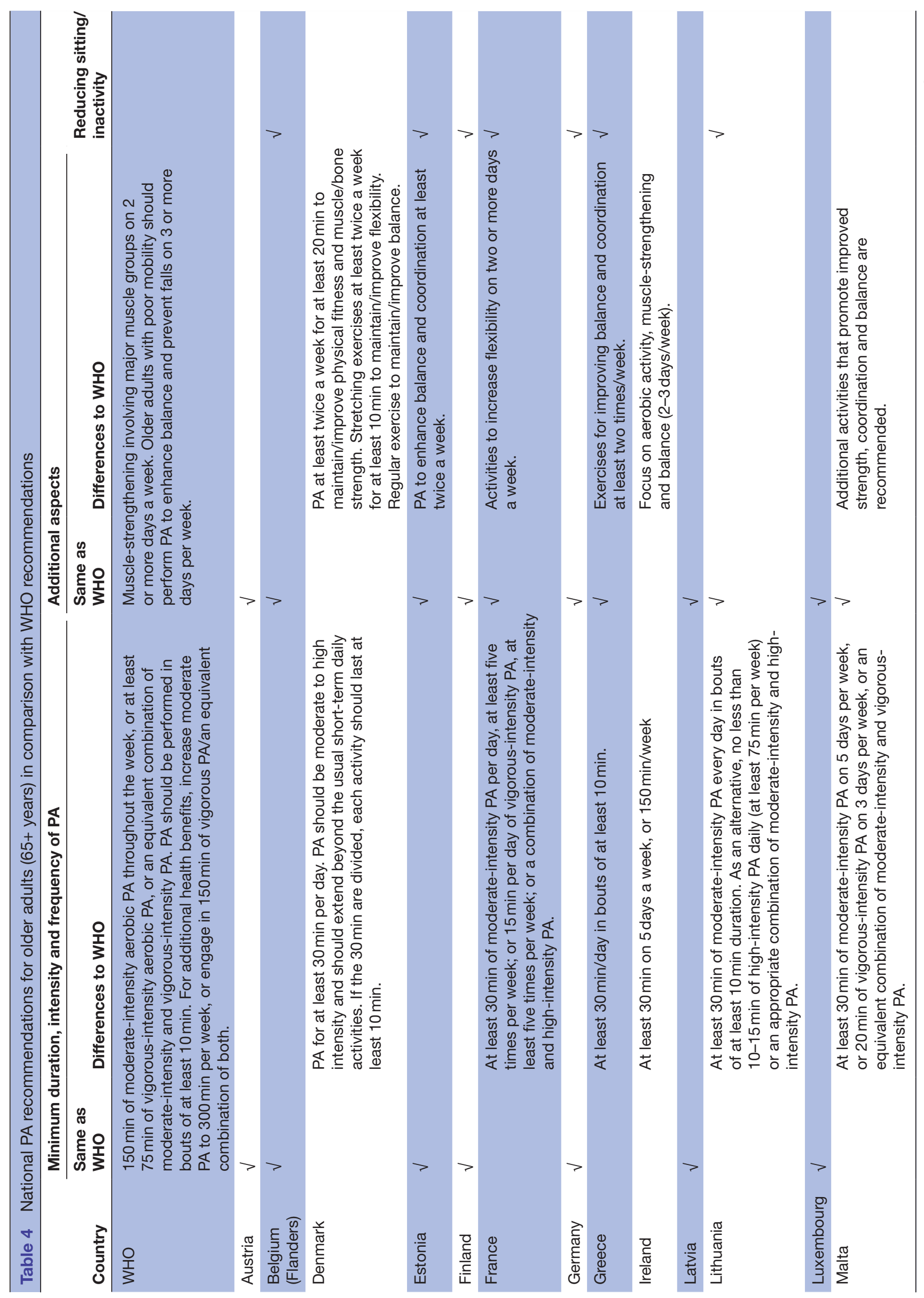


and retrieve than others. While some recommendations are high-profile documents that are easily found on search engines, advertised on dedicated websites and sport an official-looking layout, some others are hard to identify as government documents and exist only on national-language websites. In this context, there is obviously a bias towards countries whose native language is English and those that have chosen to publish supplementary English language versions of their recommendations. We have attempted to overcome this problem by relying both on fellow PA researchers in the respective countries, the expertise of the WHO Regional Office for Europe and, where necessary, direct inquiry with the national PA Focal Points to ensure that all existing documents were reliably identified and obtained for our analysis.

The language barrier is always one of the greatest potential issues in a cross-country comparison, especially when 21 different languages are involved as in this case. We worked to solve this problem by using a combination of electronic translation and verification of our initial translations by native speakers with a thorough background in PA promotion. In our specific case, the issue was somewhat alleviated by the fact that most recommendations were rather concise and did not use complicated language.

All in all, we believe that our analysis, building on unique information obtained by the EC and WHO directly from national governments, provides an excellent snapshot of existing PA recommendations in the EU, allowing us both to assess the current situation in the Union and the progress made in the last years.

Our results show that the large majority of EU Member States currently either have national PA recommendations in place or are in the process of developing them. In addition, there is a general tendency for Member States (13 out of 20) to build their recommendations on the 2010 WHO Global Recommendations ${ }^{4}$ (and, by extension, the PA Guidelines for Americans). ${ }^{5}$ A minority of seven countries based their recommendations on other documents such as the slightly older CDC/ACSM recommendations. ${ }^{39}$ Most of the countries (except for Austria, Finland and Ireland) published their national PA recommendations in the years after WHO global recommendations were released, but it may have taken a while for these new recommendations to be universally known.

Children and adolescents are arguably the age group with the greatest variation between countries, especially regarding the number and range of age brackets for which separate recommendations exist. At the time of data collection, WHO recommendations started at the age of 5 years, but 10 countries had already added information for younger age groups. This may point to the relevance of this group for national policymaking and also the fact that PA needs diverge substantially along the continuum between very young children and teenagers, and the evidence base for different age subgroups is constantly expanding. 
Table 5 National physical activity recommendations for special populations in EU Member States

Publication year

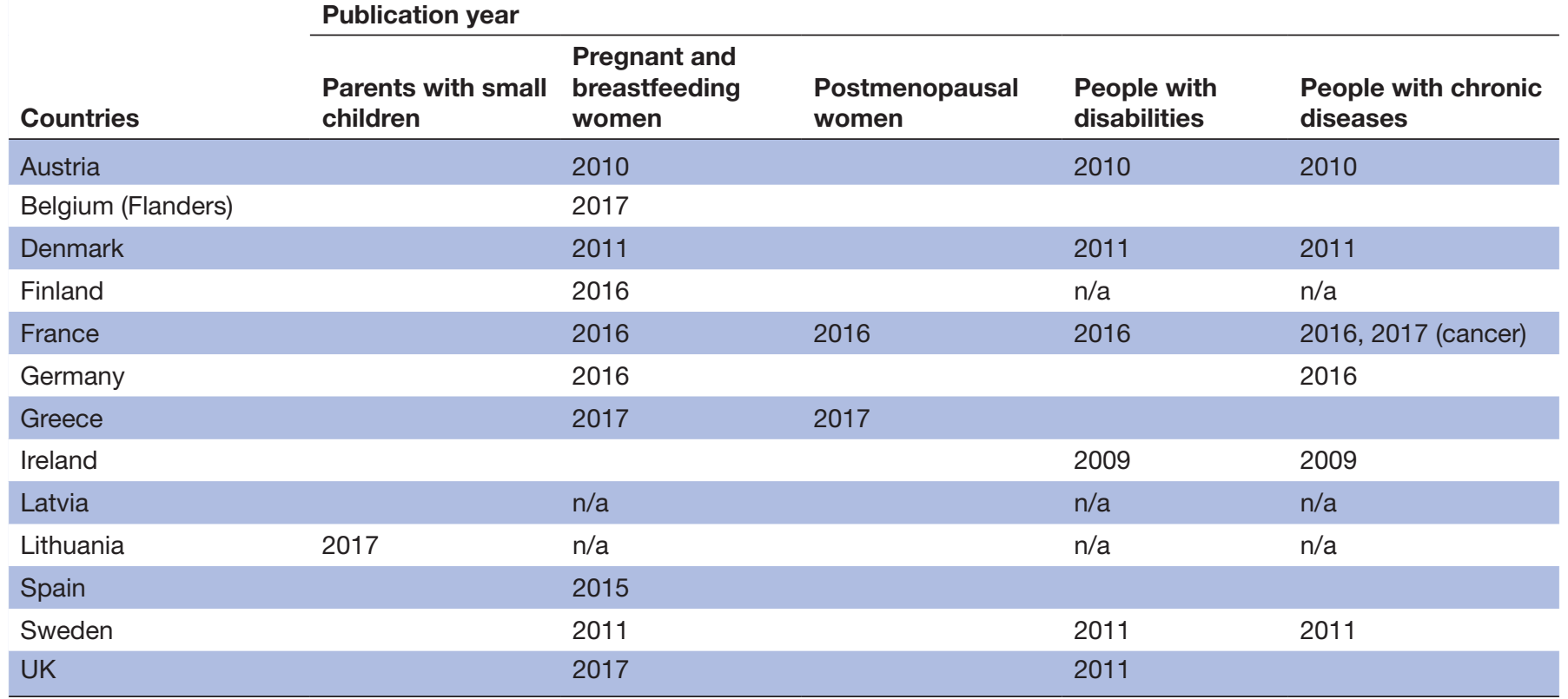

$\mathrm{n} / \mathrm{a}$, year of publication is not available.

Comparing our results to previous studies, we find that the number of countries in the $\mathrm{EU}$ with national PA recommendations has clearly increased over time, from 16 in $2011^{11}$ via 19 in $2015^{18}$ to 23 in 2018. National PA recommendations for children and adults were available for 21 countries, which is almost twice as many as in 2011 (11 for children and 12 for adults). ${ }^{11}$ The development is most clearly visible for older adults: in 2011, only five documents were available for analysis ${ }^{11}$; by 2018 , this number had increased to 18 .

The analysis also showed that many countries have mentioned special population groups in their recommendations in recent years. More than half (12) of reviewed documents include recommendations for women during pregnancy and breastfeeding, and several countries (nine) specified PA recommendations for people with chronic diseases. A few (two) also add recommendations for postmenopausal women. Special target groups seem to be a relatively new topic, as they do not appear in previous analyses of PA recommendations. ${ }^{11} 18$

Finally, the number of countries that incorporated recommendations on avoiding prolonged periods of sitting or inactivity has also increased. In 2018, 13 countries had such recommendations for children, 11 for adults and 10 for older adults. These figures had also been substantially lower in 2011, both for children and adolescents (four countries) as well as for adults and older adults (UK only). ${ }^{11}$

By contrast, specific recommendations on reducing or maintaining body weight remain relatively uncommon and are only mentioned in the current PA recommendations of three EU Member States.

\section{CONCLUSION}

This article has presented an overview of the current status of PA recommendations in EU Member States. It can be viewed in the context of efforts by the EC to monitor the progress of implementation of the Council Recommendation on HEPA across Sectors and by WHO to build capacity for PA promotion in the European Region. It also helps highlight current developments in the field (eg, further differentiation of age groups, needs of special populations, relevance of sedentary behaviour and weight management) and the extent to which new research evidence is translated into policy development. Some of these new additions may also be reflected in the planned update to the 2010 WHO Global Recommendations, work on which began in the second half of 2019. ${ }^{51}$

Our findings may also help inspire policy development in other countries of the WHO European Region, who may, for example, look to EU countries with comparable population size, geography or PA culture in order to decide how to best adopt and adapt basic WHO recommendations to their own national situation. In this context, it may also be interesting to analyse in greater detail which processes, tools and stakeholders countries used to draw up their national recommendations. Preliminary data from our survey indicate that information on guideline development processes is currently available for five of the $28 \mathrm{EU}$ Member States. These countries used different combinations of approaches, including systematic literature reviews (three countries), expert consultation (four countries) and analysis/adaptation of existing recommendations issued by WHO or other national governments (four countries). However, further research would be needed to obtain more comprehensive information from all EU Member States and potentially 
make comparisons with other national guideline development processes around the world.

From a scientific point of view, more research may also be needed on the effectiveness of national PA recommendations, that is, their direct impact on population-level PA behaviour and the extent to which they guide (public) health professionals in their efforts to promote PA. A related question is to what extent national adaptations of basic WHO recommendations actually improve the effectiveness of PA promotion, and whether these effects justify the effort of developing country-specific recommendations.

The EU Physical Activity Focal Points Network was instrumental both in collecting the data on which this study is based and in fostering exchange between EU Member States on how to improve and harmonise PA promotion for all citizens of the Union. This analysis is therefore also testimony of the utility of international collaboration in health promotion, both between EU Member States as well as between the EC and WHO.

Acknowledgements We would like to thank the national representatives of the EU Physical Activity Focal Point Network for their support in collecting the data for this article. We would also like to thank Tuula Aira, Jacopo Cristini, Gregor Jurak, Susanna Kugelberg, Nemanja Lakicevic, Lorena Miranda, Paschalis-0dysseas Moysidis, Jana Pelclova, Julia Soquet and Nina Vischer for verifying specific details in national physical activity $(\mathrm{PA})$ recommendation documents that were published in languages not spoken by the authors.

Contributors PG, KA-O and AT conceptualised the study. SW and RM developed the survey questionnaire and collected the survey data. STM supported data management during the survey. JJB and SW supervised the survey. PG, AT and KA-0 analysed the survey data. AT obtained and analysed national recommendation documents. PG and KA-O collected additional information from experts and Physical Activity Focal Points. PG drafted the manuscript. All authors participated in the revision of the article. All authors contributed to and have approved the final manuscript.

Funding The authors have not declared a specific grant for this research from any funding agency in the public, commercial or not-for-profit sectors.

Disclaimer The writing group takes sole responsibility for the content of this article, and the content of this article reflects the views of the authors only. JB and SW are staff members of the WHO. The authors alone are responsible for the views expressed in this publication, and they do not necessarily represent the decisions or the stated policy of the WHO.

Competing interests None declared.

Patient consent for publication Not required.

Ethics approval Ethical approval not required for the use of country-level policy data as included in this study.

Provenance and peer review Not commissioned; externally peer reviewed.

Data availability statement Data are available on reasonable, written request from the WHO Regional Office for Europe, but written consent of the Physical Activity Focal Points of involved countries, the European Commission and the WHO Regional Office for Europe may be required.

Open access This is an open access article distributed in accordance with the Creative Commons Attribution Non Commercial (CC BY-NC 4.0) license, which permits others to distribute, remix, adapt, build upon this work noncommercially, and license their derivative works on different terms, provided the original work is properly cited, appropriate credit is given, any changes made indicated, and the use is non-commercial. See: http://creativecommons.org/ licenses/by-nc/4.0/.

\section{ORCID iDs}

Peter Gelius http://orcid.org/0000-0002-4120-4996

Romeu Mendes http://orcid.org/0000-0002-3806-438X

Sara Tribuzi Morais http://orcid.org/0000-0002-6584-1316
REFERENCES

1 World Health Organisation. Global strategy on diet, physical activity and health, 2004.

2 World Health Organisation. Physical activity strategy for the who European region 2016-2025, 2015.

3 World Health Organisation. Global action plan on physical activity 2018-2030: more active people for a healthier world. Geneva, 2018.

4 World Health Organisation. Global recommendations on physical activity for health. Geneva, 2010.

5 U.S. Department of Health and Human Services. 2008 physical activity guidelines for Americans. be active, healthy, and happy! 2008.

6 Pate RR, Pratt M, Blair SN, et al. Physical activity and public health. A recommendation from the centers for disease control and prevention and the American College of sports medicine. JAMA 1995;273:402-7.

7 European Commission. Eu physical activity guidelines. recommended policy actions in support of health-enhancing physical activity, 2008.

8 Official Journal of the European Union. Council recommendation of 26 November 2013 on promoting health-enhancing physical activity across sectors, 2013.

9 Cameron C, Craig CL, Bull FC, et al. Canada's physical activity guides: has their release had an impact? Can J Public Health 2007;98:S161-9.

10 Rütten A, Abu-Omar K, Messing S, et al. How can the impact of national recommendations for physical activity be increased? experiences from Germany. Health Res Policy Syst 2018;16:121.

11 Kahlmeier S, Wijnhoven TMA, Alpiger P, et al. National physical activity recommendations: systematic overview and analysis of the situation in European countries. BMC Public Health 2015;15:133.

12 European Commission. Commission staff working document: $A$ monitoring framework for the implementation of policies to promote healthenhancing physical activity (HEPA), based on the EU Physical Activity Guidelines. SWD(2013) 310 final. Brussels: European Commission, ed, 2013.

13 U.S. Department of Health and Human Services. Physical activity guidelines for Americans. 2nd edn. Washington, DC, 2018.

14 Tremblay MS, Warburton DE, Janssen I, et al. New Canadian physical activity guidelines. Appl Physiol Nutr Metab 2011;36:47-58.

15 Tremblay MS, Chaput J-P, Adamo KB, et al. Canadian 24-Hour Movement Guidelines for the Early Years (0-4 years): An Integration of Physical Activity, Sedentary Behaviour, and Sleep. BMC Public Health 2017;17:874.

16 Bellew B, Schöeppe S, Bull FC, et al. The rise and fall of Australian physical activity policy 1996 - 2006: a national review framed in an international context. Aust New Zealand Health Policy 2008;5:18.

17 Department of Health. Australia's physical activity and sedentary behaviour guidelines, 2014.

18 Breda J, Jakovljevic J, Rathmes G, et al. Promoting health-enhancing physical activity in Europe: current state of surveillance, policy development and implementation. Health Policy 2018;122:519-27.

19 World Health Organisation. Physical activity factsheets for the 28 European Union member states of the who European region. Copenhagen: WHO Regional Office for Europe, 2018.

20 Vlaams Instituut Gezond Leven. Vlaamse gezondheidsaanbevelingen sedentair gedrag (lang stilzitten) en lichaamsbeweging [Flemish health recommendations on sedentary behaviour (long sitting) and physical activity]. Brussel: Vlaams Instituut Gezond Leven vzw, 2017.

21 Plan Prévention et Promotion de la Santé en Wallonie [Plan for Prevention and Health Promotion in Wallonia].

22 Rütten A, Pfeifer K. National recommendations for physical activity and physical activity promotion. Erlangen: FAU University Press, 2016.

23 Ministry of education. Recommendations for the physical activity of school-aged children. Helsinki, 2008.

24 Sveikatos mokymo ir ligu prevencijos centras. Fizinio aktyvumo rekomendacijos 3 amžiaus grupėms [Physical activity recommendations for 3 age groups] Vilnius: Lietuvos Respublikos sveikatos apsaugos ministerija (Ministry of Health Republic of Lithuania). Available: https://sam.Irv.It/It/veiklos-sritys/visuomenessveikatos-prieziura/mityba-ir-fizinis-aktyvumas-2/fizinisaktyvumas-mytyba-ir-fizinis-aktyvumas/rekomendacijos [Accessed Mar 2019].

25 Titze S, Ring-Dimitriou S, Schober PH, et al. Österreichische Empfehlungen für gesundheitswirksame Bewegung [Austrian recommendations for health-enhancing physical activity]. Wien: Fonds Gesundes Österreich, 2010.

26 Danish Health Authority. Recommendations for children and adolescents (5-17 years old) Copenhagen, 2014. Available: https://www.sst.dk/en/health-and-lifestyle/physical-activity/ recommendations/recommendations-for-children-and-adolescents[Accessed Mar 2019]. 
27 Agence nationale de sécurité sanitaire de l'alimentation, de l'environnement et du travail. Actualisation des repères du PNNS - Révisions des repères relatifs l'activité physique et la sédentarité [Revisions of benchmarks relating to physical activity and sedentary lifestyle]. Maisons-Alfort, 2016.

28 World Health Organisation. Guidelines on physical activity, sedentary behaviour and sleep for children under 5 years of age. Geneva: World Health Organisation, 2019

29 Ministry of the Education and Culture. Finnish recommendations for physical activity in early childhood 2016. Joy, play and doing together, 2016.

30 Slimību profilakses un kontroles centrs (Center for Disease Prevention and control). Fizisko aktivitāšu ieteikumi Latvijas iedzīvotājiem [Physical activity recommendations for Latvian population], 2011. Available: https://spkc.gov.lv/upload/Veicin\%C4\% 81\%C5\%A1ana/Fiziskas\%20aktivitates/fizisko_aktivitu_ieteikumi_ latvijas iedzvotjiem.pdf

31 Ministerio de Sanidad, Servicios Sociales e Igualdad. Actividad Física para la Salud y Reducción del Sedentarismo. Recomendaciones para la población [Physical activity for health and reduction of sedentary lifestyle. Recommendations for the population]. Madrid: Ministerio de sanidad, servicios sociales e igualdad centro de publicaciones, 2015.

32 Department of Health, Physical Activity, Health Improvement and Protection. Start Active, Stay Active: A report on physical activity from the four home countries'. London: Chief Medical Officers, 2011.

33 Danish Health Authority. Recommendations for physical activity children 1-4 years old Copenhagen, 2016. Available: https://www. sst.dk/en/health-and-lifestyle/ /media/038D1AD667D14453BB02 E3AAD26F9033.ashx [Accessed Mar 2019].

34 The Institute of Preventive Medicine, Environmental and

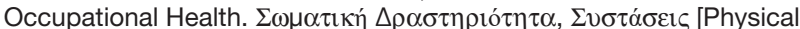
activity recommendations]. Available: http://www.diatrofikoiodigoi. $\mathrm{gr} /$ ?Page=systaseis [Accessed Mar 2019].

35 Department of Health and Children, Health Service Executive. The National guidelines on physical activity for Ireland, 2009.

36 Hrvatski zavod za javno zdravstvo. Zivjeti zdravo: tjelesno zdravlje [Healthy Living: Physical Health]. Zagreb.

37 Danish Health Authority. Recommendations for adults (18-64 years old) Copenhagen, 2014. Available: https://www.sst.dk/en/health-andlifestyle/physical-activity/recommendations/recommendations-foradults [Accessed Mar 2019].

38 Superintendence of Public Health Ministry for Health, the Elderly and Community Care. A Healthy Weight for Life: A National Strategy for Malta 2012 - 2020. Msida: Superintendence of Public Health, 2012.

39 Haskell WL, Lee I-M, Pate RR, et al. Physical activity and public health: updated recommendation for adults from the American College of sports medicine and the American heart association. Med Sci Sports Exerc 2007;39:1423-34.

40 Health Council of the Netherlands. Physical activity guidelines 2017. The Hague: Health Council of the Netherlands, 2017.

41 Zabolotnaja T, Zumeras R, Rimdeikienè I, et al. Tèvu su kūdikiais mankštos rekomendacijos [Physical activity recommendations for parents with babies], 2017.

42 UKK Institute. Kolme soveltavaa liikuntapiirakkaa toimintakyvyn mukaan [Three suitable exercise pies according to persons movement ability]. Available: http://www.ukkinstituutti.fi/ liikuntapiirakka/soveltavat_liikuntapiirakat [Accessed Mar 2019].

43 Yrkesföreningar Fysisk Aktivitet. Hur mycket fysisk aktivitet behöver barn och ungdomar? [How much physical activity do children and young people need?]: Yrkesföreningar Fysisk Aktivitet. Available: http://www.fyss.se/rekommendationer-for-fysisk-aktivitet/for-barnoch-ungdomar/ [Accessed Mar 2019].

44 Danish Health Authority. Recommendations for older people 65 years old and older) Copenhagen, 2014. Available: https://www. sst.dk/en/health-and-lifestyle/physical-activity/recommendations/ recommendations-for-older-people- [Accessed Mar 2019].

45 Yrkesföreningar för Fysisk Aktivitet. Rekommendationer Om fysisk aktivitet för vuxna: Yrkesföreningar för Fysisk Aktivitet, 2011. Available: http://www.yfa.se/rekommendationer-for-fysisk-aktivitet/ [Accessed Mar 2019].

46 Istitut National du Cancer. Bénéfices de l'activité physique pendant et après cancer. Des connaissances scientifiques aux repères pratique [Benefits of physical activity during and after cancer. From scientific knowledge to practical benchmarks]. Istitut National du Cancer, 2017.

47 Magyar Diáksport Szövetség [The Hungarian Student Sport Association]. Hivatalosan is elstartolt a DO60 mozgalom a HIPE 2018 - nemzetközi testnevelési konferencián \#társak \#játék [The DO60 movement at HIPE 2018 - international bodybuilding conference is officially started \#people \#game], 2018. Available: http://www.mdsz. hu/hirek-hu/mdsz-hu-hu/2018/11/15/hivatalosan-is-elstartolt-a- do60-mozgalom-a-hipe-2018-nemzetkozi-testnevelesi-konferenciantarsak-jatek/ [Accessed 8 Aug 2019].

48 De Mei B, Cadeddu C, Luzi P, et al. editors. Movimento, sport e salute: l'importanza delle politiche di promozione dell'attività fisica e le ricadute sulla collettività [Movement, sport and health: the importance of policies to promote physical activity and the effects on the community]. Roma: Istituto Superiore di Sanità, 2018.

49 Palamentary secritariat for youth, sport and volontary organisations,. Aiming higher. An overview of the National strategy for sport and physical activity in Malta, 2019.

50 Foster C. Overview of the 2019 physical activity. guidelines and implementation plans, 2018. Available: http://www.fuse.ac.uk/media/ sites/researchwebsites/fuse/Overview\%20of\%20the\%202019\% 20Physical\%20Guidelines\%20and\%20implementation\%20plans\% 20-\%20Charlie\%20Foster.pdf [Accessed Aug 2019].

51 World Health Organisation. Call for expression of interest to participate in the who Guideline development group for the updating of the 2010 global recommendations on physical activity in youth. Adults and Older Adults Genewa: World Health Organisation, 2019.

52 Ministerstvo zdravotnictví. Zdraví 2020 Národní strategie ochrany a podpory zdraví a prevence nemocí. Akchí plán c. 1: Podpora pohybové aktivity na období 2015-2020 [Health 2020 National strategy for the protection and promotion of Health and disease prevention. Action Plan 1: support for physical activity 2015-2020]: Ministerstvo zdravotnictví, 2015. Available: http://www.mzcr.cz/ Admin/_upload/files/5/ak\%C4\%8Dn\%C3\%AD\%20pl\%C3\% A1ny\%20-\%20p\%C5\%99\%C3\%ADlohy/AP\%2001\%20podpora\% 20pohybov\%C3\%A9\%20aktivity.pdf [Accessed Apr 2019].

53 Danish Health Authority. Recommendations for pregnant women Copenhagen, 2014. Available: https://www.sst.dk/en/health-andlifestyle/physical-activity/recommendations/pregnant-women [Accessed Mar 2019].

54 Danish Health Authority. Recommendations for physical activity infants younger than 1 year old Copenhagen, 2016. Available: https:// www.sst.dk/en/health-and-lifestyle/ /media/4D712D1E17794FCC A10B18B3BE8CD0DD.ashx [Accessed Mar 2019].

55 Tervise Arengu Instituut. Kehalise aktiivsuse soovitused lastele ja noortele [Recommendations for physical activity for children and young people], 2015. Available: http://www.terviseinfo.ee/et/ valdkonnad/liikumine/soovitused-liikumiseks/lastele-ja-noortele [Accessed Mar 2019].

56 Tervise Arengu Instituut. Kehalise aktiivsuse soovitused täiskasvanutele [Recommendations for physical activity for adults], 2015. Available: http://www.terviseinfo.ee/et/valdkonnad/liikumine/ soovitused-liikumiseks/taiskasvanutele [Accessed Mar 2019].

57 Tervise Arengu Instituut. Kehalise aktiivsuse soovitused eakatele [Recommendations for physical activity for the elderly], 2015 Available: http://www.terviseinfo.ee/et/valdkonnad/liikumine/ soovitused-liikumiseks/eakatele [Accessed Mar 2019].

58 Ministry of social affairs and Health, Finland. Reduce sedentary time - get healthier! national recommendations to reduce sedentary time. Helsinki, 2015.

59 UKK Institute. Terveysliikunnan suositus yli 65-vuotiaille [Physical activity recommendations for people over 65 years], 2008. Available: http://www.ukkinstituutti.fi/filebank/2890-UKK-liikuntapiirakka-yli-65v-tulostettava.pdf [Accessed Mar 2019].

60 UKK Institute. Physical activity pie, 2009. Available: http://www. ukkinstituutti.fi/en/products-services/physical_activity_pie [Accessed Mar 2019].

61 UKK Institute. Physical exercise during and after pregnancy, 2009. Available: http://www.ukkinstituutti.fi/filebank/276-englanti.pdf [Accessed Mar 2019].

62 évi CXC. törvény a nemzeti köznevelésröl [Law on national public education]: Nemzeti Jogszabálytár 2011.

63 Ministero della Salute. Informativa OMS: attivit fisica IWHO information: physical activity], 2014.

64 Ministère de la Santé (Ministerium für Gesundheit). Ernährung und Bewegung [Nutrition and physical activity], 2016.

65 Bratislava. Národný akčný plán pre podporu pohybovej aktivity na roky 2017 - 2020 [National Action Plan to Support Physical Activity for 2017-2020], 2017.

66 Resolucija o nacionalnem programu o prehrani in telesni dejavnosti za zdravje 2015-2025 [Resolution on the national programme on nutrition and physical activity for health 2015-2025] 2015.

67 Department of Health and Social Care. Physical activity in pregnancy infographic London, 2017. Available: https://assets.publishing. service.gov.uk/government/uploads/system/uploads/attachment_ data/file/622336/CMO_physical_activity__pregnant_women_ infographic.jpg [Accessed Aug 2019]. 